\title{
KERATINOLYTIC PROTEASE PRODUCTION BY BACILLUS CEREUS STRAIN PS03 UNDER SUBMERGED FERMENTATION: OPTIMIZATION AND CHARACTERIZATION
}

\author{
M.D. BalaKumaran ${ }^{1}$ and R. Santhi ${ }^{2 *}$ \\ ${ }^{1}$ Department of Biotechnology, D.G. Vaishnav College, Arumbakkam, Chennai, TN, India \\ ${ }^{2}$ Tagore College of Arts and Science, Chromepet, Chennai, TN, India \\ *Corresponding author’s email: shanmkands@gmail.com
}

\begin{abstract}
In the present study, chicken feather powder was screened for its application as the substrate for the production of keratinolytic protease by Bacillus subtilis strain PS03. Bacillus subtilis produced a high level of keratinolytic protease using chicken feather powder as substrate. With feather powder as substrate, physical factors such as incubation time, $\mathrm{pH}$ and temperature were optimized for increased keratinolytic protease production by Bacillus subtilis. The enzyme production was enhanced when using maltose as carbon source and yeast extract as nitrogen sources. SDS-PAGE analysis indicated the molecular weight of $46 \mathrm{kDa}$ of the partially purified keratinolytic protease. The keratinolytic protease enzyme was stable over a $\mathrm{pH}$ range of $6-9$ and temperature range of $35-50^{\circ} \mathrm{C}$ with maximum activity at $\mathrm{pH} 9$ and $40^{\circ} \mathrm{C}$. $\mathrm{Based}$ on the results, the use of feather powder as substrate for keratinolytic protease production is cost effective and is easy to scale up. Considering the availability and cost, chicken feather powder is considered as an ideal substrate for keratinolytic protease production in an industrial point of view.
\end{abstract}

Keywords: Feather powder; Bacillus subilis PS03; keratinolytic protease

\section{Introduction}

Microorganisms serve as the production warehouse for many industrially important enzymes (Mitidieri et al., 2006). Especially, proteolytic enzymes find their application in a wide range of industries such as pharmaceutical, food, animal feed, bioremediation, leather, detergent, paper, textiles, etc. The selection of microorganisms having potential enzyme activity will have substantial impacts at present and in future (Vermelho et al., 2013). Keratin, the structural protein component of hair and feathers is an insoluble protein resistant to microbial degradation due to the tight packing of the protein chain (Mazotto et al., 2011). Keratin can be degraded by keratinolytic enzymes produced by certain species of the genus Bacillus (Cedrola et al., 2012) and fungi (Gradisar et al., 2005).

The keratinolytic proteases play an important role in the enzymatic production of feather meal and feed additives for cattle (Odetallah et al., 2005), amino acid production, leather and detergent industries, etc. (Mazotto et al., 2011; Cedrola et al., 2012). After enzyme treatment the insoluble feather can be transformed into either fertilizers or feeds and also used in the amino acid production. Bacillus subtilis is one of the most important industrial bacterial species that produces a variety of enzymes such as amylases, cellulase and proteases (Morya et al., 2012). Enzymes from Bacillus sp. have been used in food industries for several decades. Even though their proteases have been studied, reports on keratinolytic protease production by Bacillus subtilis are not in-depth (Lopes et al., 2011). With these backdrops, the present study aimed to evaluate the keratinolytic enzyme production by Bacillus subtilis PS03 in submerged fermentation, its optimization and characterization.

\section{Methodology}

\section{Bacterial Strain}

The proteolytic bacteria, Bacillus subtilis strain PS03 isolated from tannery effluent contaminated soil was used for the present investigation.

\section{Screening for Keratinolytic Enzyme}

The proteolytic bacteria were streaked on to keratin-agar plates consisting (g/l): keratin, 10; peptone, 5; yeast extract, $1 ; \mathrm{K}_{2} \mathrm{HPO}_{4}, 1 ; \mathrm{MgSO}_{4} .7 \mathrm{H}_{2} \mathrm{O}, 0.2 ; \mathrm{CaCl}_{2}, 0.1 ; \mathrm{Na}_{2} \mathrm{CO}_{3}, 10$; agar-agar, 15 (Han et al., 2012). After 48 h of incubation, 
keratinolytic protease production was evidenced by the appearance of clear zone around the colony.

\section{Keratinolytic Enzyme Production}

About a loopful culture of Bacillus subtilis PS03 was inoculated on to inoculation medium which consists $(\mathrm{g} / \mathrm{l})$ : peptone, 5; beef extract, 1.5; yeast extract, 1.5; sodium chloride, 5. In order to examine the keratinolytic enzyme production, $1 \mathrm{ml}$ of the above inoculum was added to 100 $\mathrm{ml}$ of culture medium containing ( $\mathrm{g} / \mathrm{l})$ : feather powder, 30 ; peptone, 5; $\mathrm{MgSO}_{4}, 0.1$; yeast extract, 5; $\mathrm{K}_{2} \mathrm{HPO}_{4}, 1$ (Han et al., 2012). For analyzing feather degradation, $0.1 \%$ of grounded feather powder was added to the basal medium. The medium was incubated at $37^{\circ} \mathrm{C}$ for $48 \mathrm{~h}$. The culture medium was then centrifuged and the cell free supernatant was used for assay procedures.

\section{Assay for Keratinolytic Enzyme}

The keratinolytic activity was assayed by adding $100 \mu \mathrm{l}$ of cell free culture filtrate to $400 \mu \mathrm{l}$ of azokeratin $(10 \mathrm{mg} / \mathrm{ml})$ dissolved in $0.1 \mathrm{M}$ phosphate $(\mathrm{pH}$ 8.0) and incubated for 15 min at $50^{\circ} \mathrm{C}$. The reaction was then stopped by adding $2 \mathrm{ml}$ of trichloroacetic acid and the mixture was centrifuged at $10000 \mathrm{rpm}$ for $5 \mathrm{mins}$. The absorbance of the supernatant was measured at $440 \mathrm{~nm}$. One enzyme unit can be defined as the amount of enzyme required to increase the absorbance of 0.01 (Aruna Devi and Lakshmi, 2014). Protein concentration was determined by Bradford method (Bradford, 1976) using bovine serum albumin as standard.

\section{Optimization of Process Parameters}

The process parameters involved in the production of keratinolytic enzymes were optimized further. The factors considered were fermentation period (12 - $120 \mathrm{~h}), \mathrm{pH}(6-$ $11)$, temperature $\left(30-60^{\circ} \mathrm{C}\right)$, carbon sources $(1 \%$, w/w $)$ (glucose, sucrose, maltose, lactose, xylose, and starch), and nitrogen sources $(1 \%, \mathrm{w} / \mathrm{w})$ (peptone, yeast extract, ammonium nitrate, urea, and casein).

\section{Partial Purification of Keratinolytic Enzyme}

The keratinolytic protease enzyme produced under optimized conditions was partially purified using ammonium sulphate precipitation and dialysis. The cell free culture filtrate was subjected to $60 \%$ saturation of ammonium sulfate to obtain partially purified keratinolytic protease. The crude enzyme was obtained by centrifuging the precipitate at $10000 \mathrm{rpm}$ for $20 \mathrm{~min}$. The precipitate obtained was dissolved in $10 \mathrm{mM}$ sodium phosphate buffer, and dialyzed overnight using the same buffer. The partially purified keratinolytic protease enzyme was collected, concentrated and stored at $-20^{\circ} \mathrm{C}$.

\section{SDS-PAGE Analysis}

The protein purity and molecular weight of the partially purified keratinolytic protease was determined using SDSPAGE electrophoresis (Laemmli, 1970).

\section{Characterization of Keratinolytic Enzyme}

The effect of $\mathrm{pH}$ on the activity and stability of the keratinolytic enzyme was assayed by determining the enzyme activity after incubation of the enzymes at different $\mathrm{pH}$ (6-11) for $1 \mathrm{~h}$. Similarly, the effect of temperature on the keratinolytic activity and stability was determined by determining the enzyme activity after incubation of the enzymes at $30-90^{\circ} \mathrm{C}$ for $1 \mathrm{~h}$ in a constant-temperature water bath. The residual keratinolytic activity and stability was estimated quantitatively using spectrophotometer.

\section{Results and Discussion}

The Bacillus subtilis strain PS03 isolated from tannery effluent contaminated soil was used in the present investigation. The bacteria were identified using 16S rRNA sequence analysis and the nucleotide sequence were submitted to the Genbank under the accession number KT160016. This study was aimed to screen the bacteria for producing keratinolytic enzyme using keratin-agar plates. The bacterial strain was shown to produce appreciable level of keratinolytic protease enzyme. The ability of Bacillus subtilis PS03 to produce enhanced level of keratinolytic protease could offer tremendous potential for the development of biotechnological methods for the hydrolysis of feather waste (Moreira-Gasparin et al., 2009).

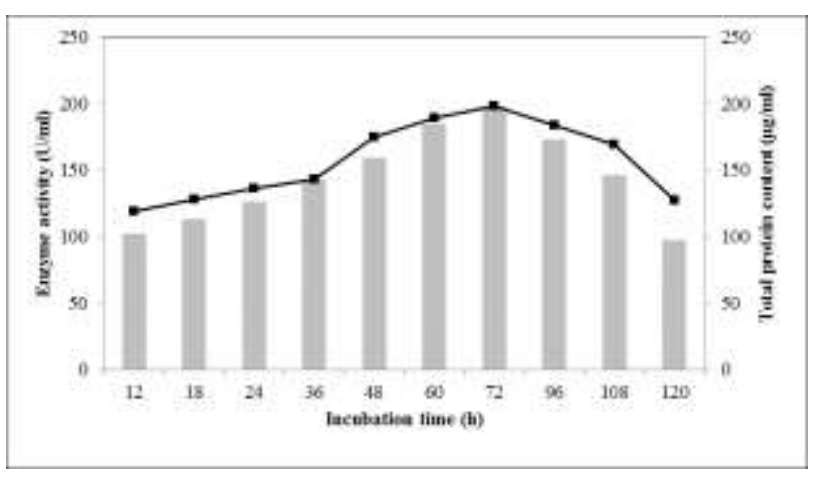

Fig. 1: Time course study on keratinolytic protease production by $B$. subtilis $\mathrm{PS} 03$

The effect of incubation time on keratinolytic protease production was studied for a period of $120 \mathrm{~h}$ at $37^{\circ} \mathrm{C}$ and reached maximum enzyme activity during $72 \mathrm{~h}$ of incubation (Fig. 1). The results have also shown that beyond $72 \mathrm{~h}$, the enzyme activity decreased considerably. These results obtained are in accordance with the observations made by George-Okafor and Mike-Anosike (2012) with Bacillus sp. Since $\mathrm{pH}$ influences the metabolic activity of bacterial cell, it was optimized. The keratinolytic protease production was observed between the $\mathrm{pH}$ range of $6-11$ and the enzyme production was maximum at $\mathrm{pH} 9$ and beyond which, substantially decreased (Fig. 2). Based on the observations, the $\mathrm{pH}$ of the production medium was kept at 9 in subsequent experiments. Prakasham et al. (2006) also found $\mathrm{pH} 9$ as optimum $\mathrm{pH}$ for keratinolytic protease production by Bacillus sp. Next to $\mathrm{pH}$, temperature plays an important role in the enzyme production. Among the tested 
temperatures, $40^{\circ} \mathrm{C}$ favored the keratinolytic protease production (Fig. 3). Temperature is one of the important factors responsible for the enzyme production as most of the substrates are heat sensitive. Similar trend of results were observed by Sivakumar et al. (2012).

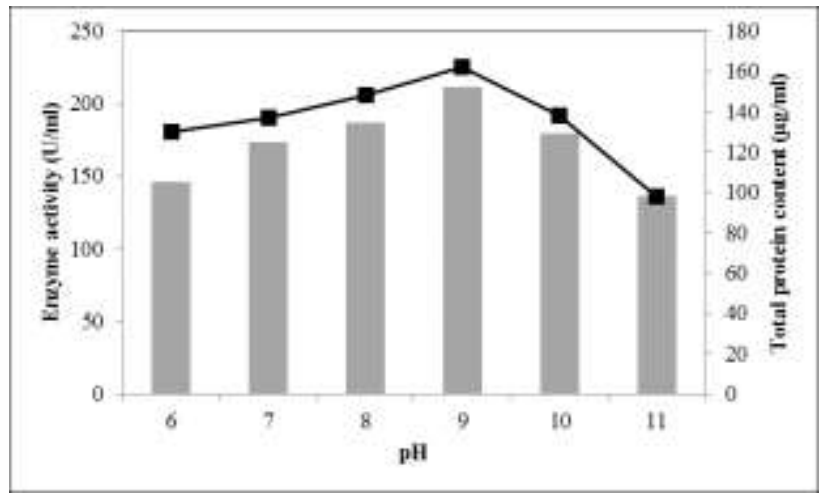

Fig. 2: Effect of $\mathrm{pH}$ on keratinolytic protease production by $B$. subtilis $\mathrm{PS} 03$

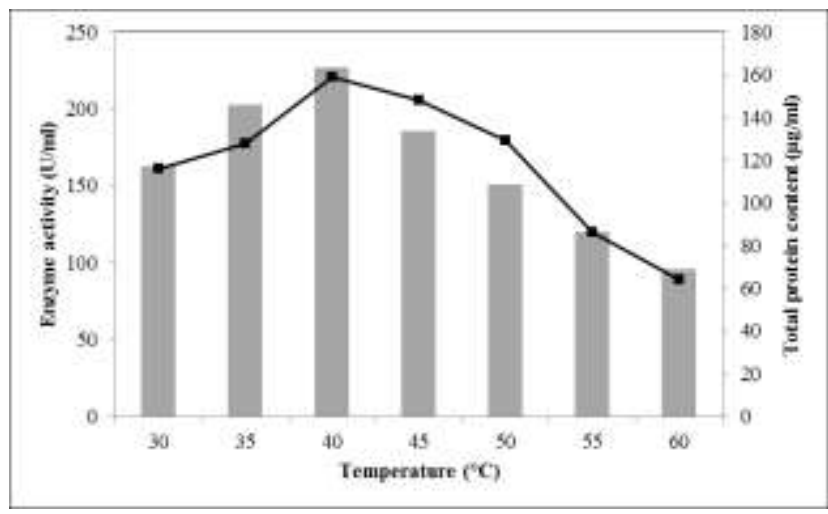

Fig. 3: Effect of temperature on keratinolytic protease production by $B$. subtilis $\mathrm{PS} 03$

The results revealed that the carbon and nitrogen sources have a major influence on the yield of keratinolytic protease. Among the carbon sources, maltose favored the maximum keratinolytic protease production followed by lactose, glucose, sucrose, xylose and starch, respectively (Fig. 4). Since, maltose is the simple sugar it can be easily utilized by the bacteria for their metabolic activities and enzyme production. The results obtained were in accordance with reports of Ellaiah et al. (2002) and Vijayaraghavan et al. (2012). Similarly, among the nitrogen sources tested, yeast extract favored maximum keratinolytic protease production followed by peptone, ammonium nitrate, casein and urea (Fig. 5). Results of similar trends were observed by Pandey et al. (2000) and Prakasham et al. (2006) who have observed the production of keratinolytic protease using different bacteria.

The keratinolytic protease present in the cell free culture filtrate was precipitated with $70 \%$ saturation of ammonium sulfate and dissolved in Tris- $\mathrm{HCl}$ buffer. The crude keratinolytic proteases were dialyzed and concentrated. The molecular weight of the partially purified keratinolytic protease enzyme was determined using SDS-PAGE analysis. The partially purified enzyme migrated as a major band with an apparent molecular weight of $46 \mathrm{kDa}$ along with few minor bands. Keratinolytic enzymes with similar molecular weights were isolated and characterized by several researchers. The molecular weight of keratinolytic enzyme was less than $50 \mathrm{kDa}$ for Bacillus cereus (Sousa et al., 2007) and was $39.5 \mathrm{kDa}$ for B. circulans (Rao et al., 2009).

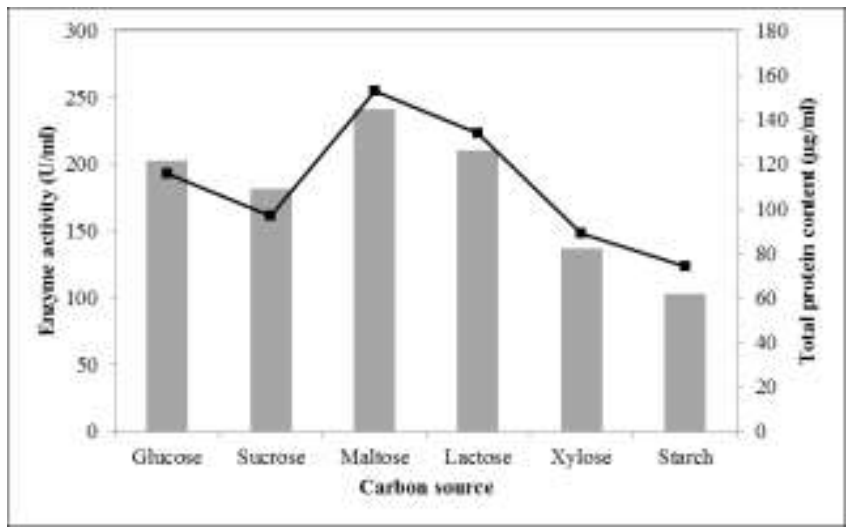

Fig. 4: Effect of carbon sources on keratinolytic protease production by $B$. subtilis PS03

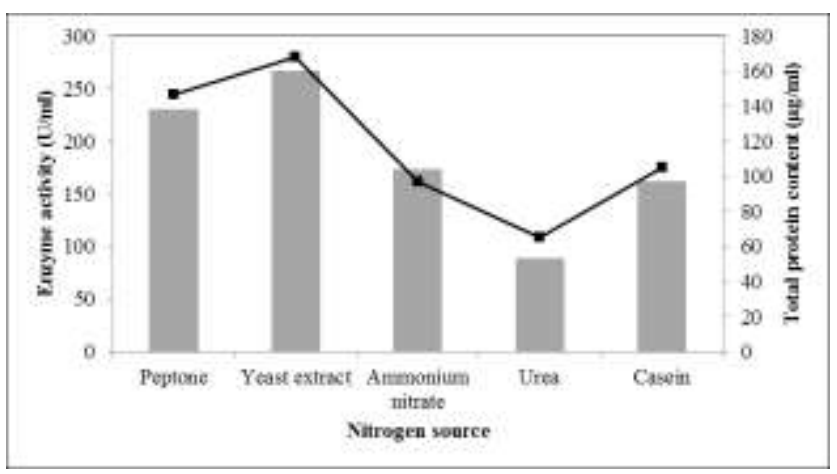

Fig. 5: Effect of nitrogen sources on keratinolytic protease production by $B$. subtilis PS03

After molecular weight determination, the effect of $\mathrm{pH}$ on the activity and stability of keratinolytic protease enzyme was studied. The keratinolytic protease was found to be active between the $\mathrm{pH}$ range of 6 to 9 and the maximum activity was recorded at $\mathrm{pH} 9$. The relative enzyme activity was recorded a maximum of $100 \%$ at $\mathrm{pH} 9$. Beyond which the enzyme activity drops to 39.4 at $\mathrm{pH} 10$ (Fig. 6). The enzyme was found to be stable upto $\mathrm{pH} 9$ for $1 \mathrm{~h}$. Results of similar trend were observed by other researchers when characterizing Bacillus sp. producing proteolytic and keratinolytic enzymes (Rajkumar et al., 2011; El-Hadj-Ali et al., 2007; Haile and Gessesse, 2012). Rao et al. (1998) have reported that the commercial bacterial keratinolytic enzymes have $\mathrm{pH}$ optima in the range from 8 to 12 and the results of the present study also found in line with his findings. 


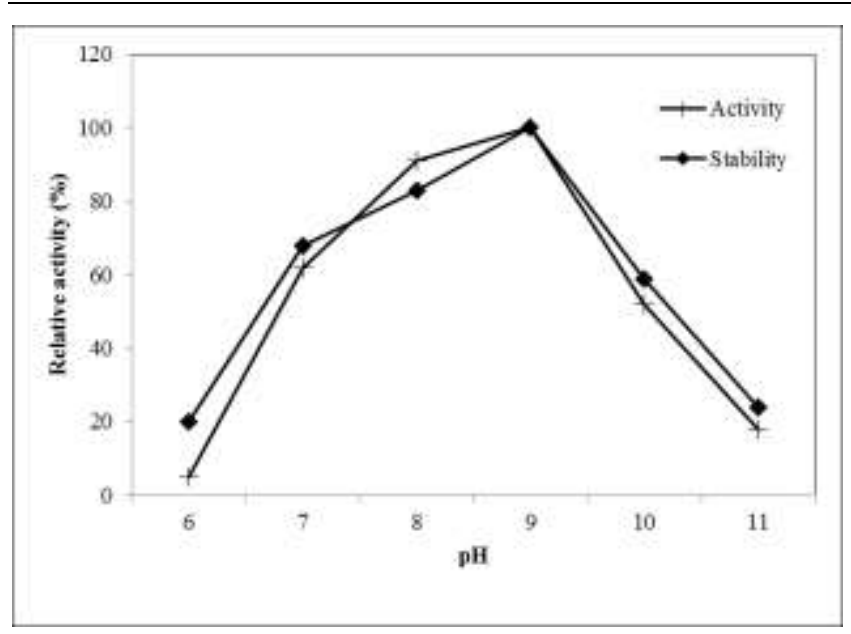

Fig. 6: Effect of $\mathrm{pH}$ on the activity and stability of keratinolytic protease

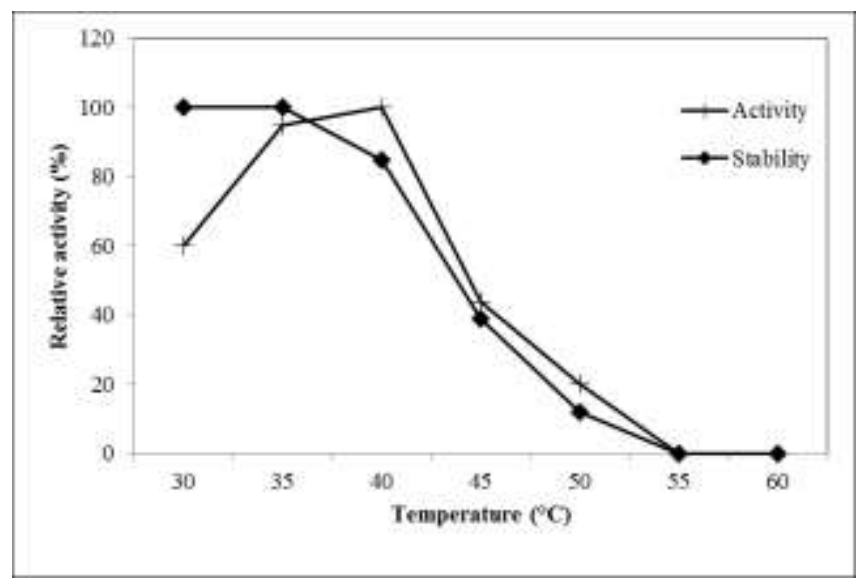

Fig. 7: Effect of temperature on the activity and stability of keratinolytic protease

After $\mathrm{pH}$, the temperature was considered as the factor to characterize the keratinolytic protease enzyme. The maximum keratinolytic protease activity recorded was between 35 and $40^{\circ} \mathrm{C}$ and the activity decreased rapidly beyond $45^{\circ} \mathrm{C}$. In case of stability, the keratinolytic protease was found to be stable up to $40^{\circ} \mathrm{C}$ for $1 \mathrm{~h}$ incubation and lost its activity at $60^{\circ} \mathrm{C}$ (Fig. 7). Shinde et al. (2012) and Haile and Gessesse (2012) also observed similar result while characterizing keratinolytic enzyme using Bacillus spp.

\section{Conclusion}

In the present study, a keratinolytic enzyme was produced using the feather powder substrate in submerged fermentation. Chicken feather powder is an ideal substrate for keratinolytic protease production in an industrial point of view, considering its cheap cost and availability. The keratinolytic protease from Bacillus subtilis PS03 was active in a wide range of $\mathrm{pH}$ and temperature. These properties of the keratinolytic protease suggest its suitable application as an additive in the leather industry and in the management of feather waste.

\section{References}

Aruna Devi D and Lakshmi VV (2014) Prolonging the Utilization of Keratinase by Entrapment of Cells. Int. J. Curr. Microbiol. App. Sci. 8: 38-44.

Bradford MM (1976) A rapid and sensitive method for the quantitation of microgram quantities of protein utilizing the principle of protein-dye binding. Analyt. Biochem. 72: 248-254. DOI: 10.1016/0003-2697(76)90527-3

Cedrola SML, Melo ACN, Mazotto AM, Lins U, Zingali RB, Rosado AS, Peixoto RS and Vermelho AB (2012) Keratinases and sulfide from Bacillus subtilis SLC to recycle feather waste. World Journal of Microbiology \& Biotechnology. 28: 1259-1269. DOI: 10.1007/s11274011-0930-0

El-Hadj-Ali N, Agrebi R, Ghorbel-Frikha B, Kanoun S and Nasri M (2007) Biochemical and molecular characterization of a detergent stable alkaline serine-protease from a newly isolated Bacillus licheniformis NH1. Enzyme Microb. Technol. 40: 515-523. DOI: 10.1016/j.enzmictec.2006.05.007

Ellaiah P, Srinivasulu B and Adinarayana K (2002) A review on microbial alkaline proteases. J. Sci. Ind. Res. 61: 690-704.

George-Okafor UO and Mike-Anosike EE (2012) Screening and optimal protease production by Bacillus sp. Sw-2 using low cost substrate medium. Res. J. Microbiol. 7: 327-336. DOI: $10.3923 / j m .2012 .327 .336$

Gradisar H, Friedrich J, Krizaj I, Jerala R (2005) Similarities and specificities of fungal keratinolytic proteases: comparison of keratinases of Paecilomyces marquandii and Doratomyces microsporus to some known proteases. Applied and Environmental Microbiology 71: 3420-3426. DOI: 10.1128/AEM.71.7.3420-3426.2005

Haile G, Gessesse A (2012) Properties of alkaline protease C45 produced by alkaliphilic Bacillus Sp. isolated from Chitu, Ethiopian Soda Lake. J. Biotechnol. Biomater. 2: 136. DOI: $10.4172 / 2155-952 X .1000136$

Han M, Luo W, Gu Q, and Yu X (2012) Isolation and characterization of a keratinolytic protease from a featherdegrading bacterium Pseudomonas aeruginosa C11. African Journal of Microbiology Research. 6(9): 22112221.

Laemmli UK (1970) Cleavage of structural proteins during the assembly of the head of bacteriophage T4. Nature 227: 680-685. DOI: $10.1038 / 227680 \mathrm{a} 0$

Lopes FC, Dedavid e Silva LA, Tichota DM, Daroit DJ, Velho RV, Pereira JQ, Corrêa APF and Brandelli A (2011) Production of proteolytic enzymes by a keratin-degrading Aspergillus niger. Enzyme Research, DOI: 10.4061/2011/487093

Mazotto AM, de Melo, ACN, Macrae A, Rosado AS, Peixoto R, Cedrola SML, Couri S, Zingali RB, Villa ALV, Rabinovitch L, Chaves JQ, Vermelho AB (2011) Biodegradation of feather waste by extracellular keratinases and gelatinases from Bacillus spp. World Journal of Microbiology \& Biotechnology 27: 1355-1365. DOI: $10.1007 / \mathrm{s} 11274-010-0586-1$ 
Mitidieri S, Martinelli AH, Schrank A, and Vainstein MH (2006) Enzymatic detergent formulation containing amylase from Aspergillus niger: a comparative study with commercial detergent formulations. Bioresource Technology 97: 12171224. DOI: 10.1016/j.biortech.2005.05.022

Moreira-Gasparin FG, de Souza CG, Costa AM, Alexandrino AM, Bracht CK, Boer CG, and Peralta RM (2009). Purification and characterization of an efficient poultry feather degrading-protease from Myrothecium verrucaria. Biodegradation 20: 727-736. DOI: 10.1007/s10532-0099260-4

Morya VK, Yadav S, Kim EK, and Yadav D (2012) In silico characterization of alkaline proteases from different species of Aspergillus. Applied Biochemistry and Biotechnology 166: 243-257. DOI: 10.1007/s12010-0119420-y

Odetallah NH, Wang JJ, Garlich JD, and Shih JC (2005) Versazyme supplementation of broiler diets improves market growth performance. Poultry Science 84: 858-864. DOI: $10.1093 / \mathrm{ps} / 84.6 .858$

Pandey A, Soccol CR, Nigam P, Brand D, Mohan R, and Roussos S (2000) Biotechnological potential of coffee pulp and coffee husk for bioprocesses. Biochem. Eng. J. 6: 153162. DOI: $10.1016 / \mathrm{S} 1369-703 \mathrm{X}(00) 00084-\mathrm{X}$

Prakasham RS, Rao CS, and Sarma PN. 2006. Green gram husk: an inexpensive substrate for alkaline protease production by Bacillus sp. in solid-state fermentation. Bioresour. Technol. 97: 1449-1454. DOI: 10.1016/j.biortech.2005.07.015

Rajkumar R, Jayappriyan KR, Rengasamy R (2011) Purification and characterization of a protease produced by Bacillus megaterium RRM2: application in detergent and dehairing industries. J. Basic Microbiol. 51(6): 614-624. DOI: $10.1002 /$ jobm. 201000517
Rao CS, Sathish T, Ravichandra P, and Prakasham RS (2009) Characterization of thermo- and detergent stable serine protease from isolated Bacillus circulans and evaluation of eco-friendly applications. Process Biochem. 44: 262-268. DOI: $10.1016 /$ j.procbio.2008.10.022

Rao MB, Tanksale AM, Ghatge MS, and Deshpande VV (1998) Molecular and biotechnological aspects of microbial proteases. Microbiol. Mol. Biol. Rev. 62: 597-635.

Shinde AA, Shaikh FK, Padul MV, and Kachole MS (2012) Bacillus subtilis RTSBA6.00, a new strain isolated from gut of Helicoverpa armigera (Lepidoptera: Noctuidae) produces chymotrypsin- like proteases.. Saudi J. Biol. Sci. 19(3): 317-323. DOI: 10.1016/j.sjbs.2012.03.001

Sivakumar T, Shankar T, Vijayabaskar P, and Ramasubramanian V (2012) Optimization for Keratinase Enzyme Production Using Bacillus thuringiensis TS2. Academic Journal of Plant Sciences 5(3): 102-109.

Sousa F, Jus S, Erbel A, Kokol V, Cavaco-Paulo A, and Gubitz GM (2007) A novel metalloprotease from Bacillus cereus for protein fibre processing. Enzyme Microb. Technol. 40: 1772-1781. DOI: 10.1016/j.enzmictec.2006.12.017

Vermelho AB, Noronha Filho EF, EDXF FM, and Bon EP (2013). Prokaryotic enzymes: diversity and biotechnological applications. In: Rosenberg, E., Stackebrand, E., DeLong, E., Thompson, F., Lory, E. (Eds.), The Prokaryotes. A Handbook on the Biology of Bacteria, fourth ed. Springer, Berlin Heidelberg, pp. 213-240. DOI: 10.1007/978-3-64231331-8_112

Vijayaraghavan P, Vijayan A, Arun A, Jenisha JK, and Vincent SG (2012) Cow dung: a potential biomass substrate for the production of detergent-stable dehairing protease by alkaliphilic Bacillus subtilis strain VV. SpringerPlus 1: 76. DOI: 10.1186/2193-1801-1-76 